\title{
Monitoring of Groundwater in the Area of a Reclaimed Municipal Waste Landfill
}

\author{
Janina Piekutin ${ }^{1}$ \\ 1 Bialystok Technical University, ul. Wiejska 45 A, 15-350 Białystok, Poland \\ e-mail: j.piekutin@pb.edu.pl
}

\begin{abstract}
The paper presents the quality of groundwater around the municipal waste landfill in the town of Kolonia Lipsk. The structure, location and operation of the landfill are presented. The aim of this work was to assess the state of groundwater quality around the reclaimed Municipal Waste Landfill in the city of Kolonia Lipsk, closed in 2012. The research was carried out in 2015 with the frequency of once a quarter for 10 selected indicators characteristic for the water pollution assessment in the area of municipal waste landfills. The water for testing was taken from three piezometers located in the vicinity of tested object, at different distances and at various depths in farm wells. Although the landfill has not been operating since 2012, the contamination of groundwater around the landfill has been identified. The lack of landfill bottom sealing and the lack of surrounding ditches indicate that the condition will last for some time.
\end{abstract}

Keywords: municipal waste, groundwater, monitoring

\section{INTRODUCTION}

Incorrect location and exploitation of landfills negatively affects all elements of the natural environment (soils, ground and surface water, plants, air), and the unsealed bottom of the landfill causes that the effluents produced by infiltrating rainwater penetrate through the ground and slopes of the landfill, thus becoming the source of a long-term pollution of soils and groundwater (Pleczyński 1999). The total amount of pollution from landfills depends on the type of waste deposited as well as the physical and chemical changes taking place in the landfill slope, in addition to the protection of the ground. The quantity and quality of pollution from the landfill depend on: the type of waste deposited, physical and chemical changes that take place in the landfill and ground protection. This also includes the chemical and physical processes taking place in the effluents affecting their chemical and physical characteristics. The substances produced as a result of biochemical processes are not fully recognized, because their chemical composition depends on the type of impurities and microorganisms taking an active part in the process. The living organisms that contribute to the decomposition process trigger biotransformation of organic pollutants (Wiater 2011, Bilitewski et al. 2006). The correct selection and legal sanctioning of the landfill site is the most difficult task in the overall management of domestic waste. Special requirements are put on the location conditions of landfills, which may cause significant deterioration of the natural conditions in the vicinity and hinder the use of the area (Rosik-Dulewska 2008).

In accordance with the Polish environmental protection law and construction law, the obligation to reclaim old landfills lies with the institutions that operate these facilities (Regulation 2013). In the period of a long-term landfilling of waste, the areas, especially underground and surface waters, around such landfills have been heavily polluted. The assessment of water pollution status should be controlled as part of a local monitoring, consisting of a piezometer network monitoring the quality of groundwater (Manczewski, Lewicki, 2012) and collection points on surface watercourses in the area of the landfill (Regulation 2013). The paper discusses the 
changes in the size of selected parameters characterizing the quality of groundwater in the area of the reclaimed Kolonia Lipsk landfill closed in 2011, located in the Podlasie province in the municipality of Kolonia Lipsk (Study 2015/2016).

The aim of present work was to assess the state of groundwater quality around the reclaimed Landfill of Municipal Waste closed in 2012 in the city of Kolonia Lipsk.

\section{Characteristics of the landfill Kolonia Lipsk}

The area of a closed landfill for non-hazardous and inert waste is located approximately $4 \mathrm{~km}$ from the city of Lipsk, by the provincial road No. 664 Augustów - state border, about $400 \mathrm{~m}$ from the nearest economic development and in an area that was not fully adapted to the applicable regulations (Bilitewski et al. 2006, Study 2016). It is surrounded by a private gravel pit, a small area of private forests, and cultivated fields.

The geophysical research (KorzeniewskaRejmer 2003), which was carried out in 1985, showed that there are highly permeable gravelsand deposits in the entire area provided for the landfill from the surface to a depth of 20-25 m (and probably deeper). No weakly permeable and impermeable soil was found within these formations, which could be an isolation for groundwater and protect it against the pollution coming from the surface (Study 2016). The groundwater table is deep at the depths below $30 \mathrm{~m}$. These waters are fed mainly from the surface due to the infiltration of rainwater. The Biebrza river valley is the receiver of groundwater from the landfill area. Recognition made outside the area of the landfill site (land where the farms are located, the underground water intakes of which may be endangered by the landfill) shows different geological structure of these areas. There are complexes of slightly permeable and impermeable fragments. Shallow wells dug in the vicinity of the landfill site, capturing the water from these formations, do not have direct hydraulic connections with the aquifer, which occurs within the gravel-sand range in the area of the landfill.

Only municipal waste was deposited on the landfill in question. The owner of the landfill located in the town of Kolonia Lipsk is the municipality of Lipsk. This facility was operated by the Municipal Utilities Plant in Lipsk in 1990-2011. According to the data from the Study of Conditions and Directions of Spatial Development of the Town and Municipality of Lipsk, the landfill covered the area of 1.02 ha. The capacity of the described object was $35700 \mathrm{~m}^{3} / 11900 \mathrm{Mg}$. The area that has been occupied by waste amounted to $6000 \mathrm{~m}^{2}$. The facility was not divided into units. The landfill had full, closed fence with a length of $533.10 \mathrm{~m}$ together with a $3 \mathrm{~m}$ wide entry gate and an insulating greenery belt. At the entrance, there was a disinfecting shower tray, with the dimensions of $7 \times 4 \mathrm{~m}$. There were boxes for secondary raw materials of $10.82 \times 4.20 \mathrm{~m}$ with the reinforced concrete structure. The resulting effluents are collected in a row insulated with foil and lined with concrete slabs. The effluents go to a concrete well. At the landfill, there is a degassing installation consisting of 8 degassing wells. Three farm wells are used as piezometers. They are located at different distances from the landfill. Reclamation of the discussed landfill included: land clearing, formation and leveling of the waste mound, and demolition of the existing building, fencing, disinfecting shower tray and boxes for secondary raw materials. The technical reclamation carried out consisted in creating the leveling, degassing, and drainage layer as well as a subsoil layer and biological reclamation layer. In the closed landfill, the waste mounds were sealed, degassing wells were built and the surrounding ditch was dug for the rainwater, discharging it into an earth evaporation reservoir. The area around the landfill was also organized, trees and shrubs were planted. No waste segregation was carried out at the landfill site. According to the data from 2011, the capacity of the collected waste in the landfill amounted to $23146.95 \mathrm{~m}^{3} / 7715.65 \mathrm{Mg}$ (Functional Utility Program 2011). The map in Figure 1 presents location of the landfill in question.

\section{MATERIAL AND METHODS}

The water for analyses was collected from the piezometers located around the tested landfill. Farm wells, located in households were used as piezometers. These farms are located near the landfill site. The first piezometer was located in the village of Kolonia Lipsk at a distance of about $600 \mathrm{~m}$ from the landfill, the second also in the same town at a distance of about $500 \mathrm{~m}$. The third research and control point was located in the village of Kurianka at a distance of about $1000 \mathrm{~m}$ from the place of waste depositing. The following parameters were tested in water samples: $\mathrm{pH}$, 


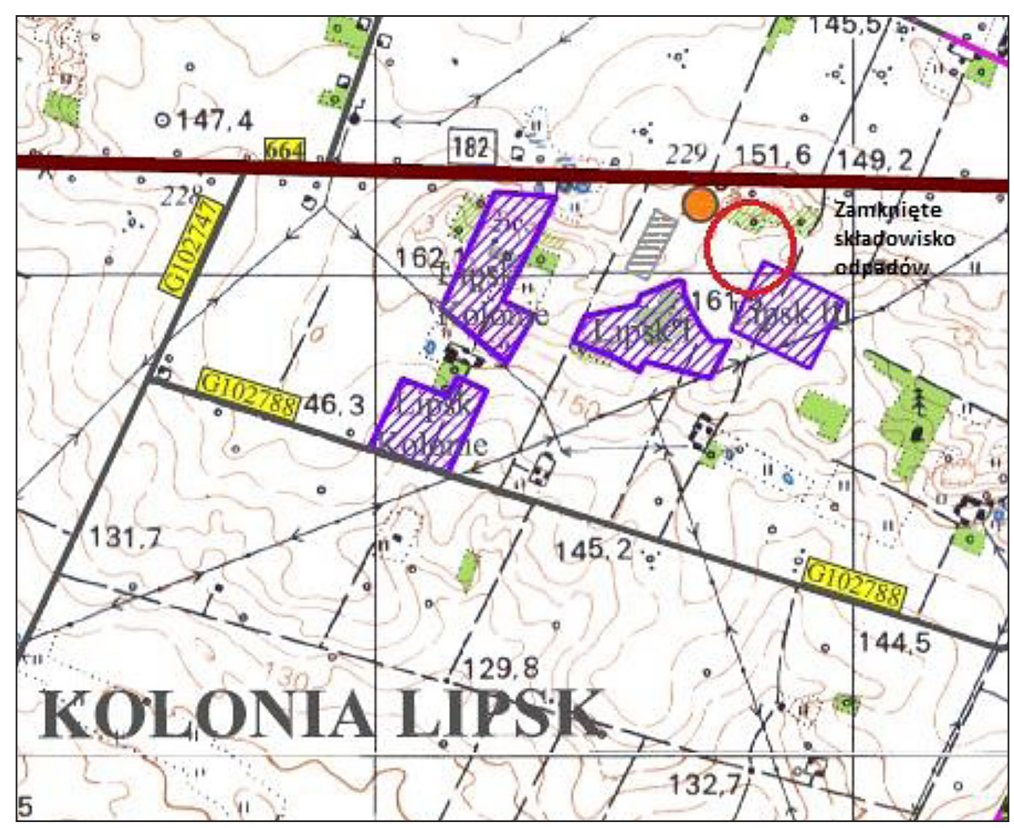

Figure 1. Location of a closed landfill in Kolonia Lipsk

electrolytic conductivity, sum of polycyclic aromatic hydrocarbons (PAH), total organic carbon (TOC) and heavy metals: cadmium (Cd), chromium $(\mathrm{Cr})$, copper $(\mathrm{Cu})$, lead $(\mathrm{Pb})$, zinc $(\mathrm{Zn})$ and mercury $(\mathrm{Hg})$. The groundwater surveys were conducted based on the following standards:

- PN-ISO 5667-11: 2004 - Water quality. Sampling. Part 11: Guidelines for the collection of groundwater samples - accredited method.

- ECO4b- 005 ed. II of 18.02.2010 - Temperature measurement of water, sewage and aqueous solutions - accredited method.

- PN-EN 27888:1999 - Water quality. Determination of specific electrical conductivity - accredited method.

- -PE-EN ISO 10523:2012 - Water quality. Determination of $\mathrm{pH}$ - accredited method.
The groundwater analyses were carried out quarterly in 2015. The work used the data obtained from the Municipal Office and the Municipal Plant in Lipsk related to the reclaimed and closed waste landfill in Kolonia Lipsk, as well as the results of water tests.

\section{RESULTS AND DISCUSSION}

The water level in the analyzed piezometers has changed (Table 1). The highest level of water table was observed in June and December in piezometer No. 1, it exceeded $20 \mathrm{~m}$, in June - 20.83 meters and $20.61 \mathrm{~m}$ in December, respectively. This was probably due to high precipitation. The lowest level of water table was

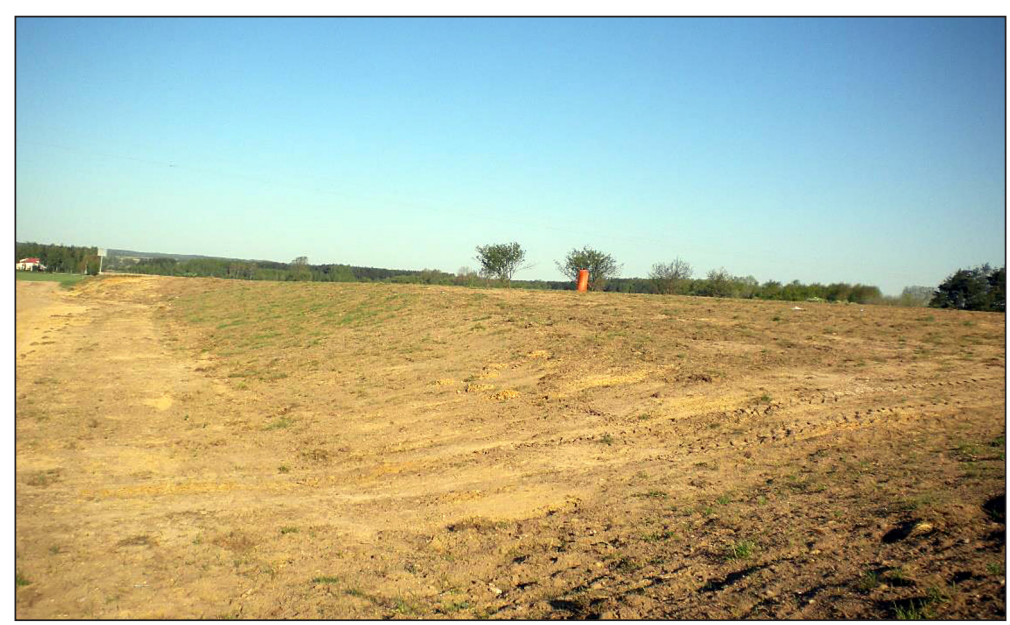

Figure 2. Reclaimed landfill site in Kolonia Lipsk 
Table 1. The level of water table in the piezometers studied and physical properties of water

\begin{tabular}{|c|c|c|c|c|c|c|c|c|c|c|c|c|}
\hline \multirow{3}{*}{ Parameter } & \multicolumn{12}{|c|}{ Piezometer } \\
\hline & \multicolumn{4}{|c|}{1} & \multicolumn{4}{|c|}{2} & \multicolumn{4}{|c|}{3} \\
\hline & III & IV & IX & XII & III & IV & IX & XII & III & IV & IX & XII \\
\hline Water table $[\mathrm{m}]$ & 19.68 & 20.83 & 19.50 & 20.61 & 17.02 & 19.05 & 16.89 & 19.20 & 8.02 & 12.68 & 10.76 & 12.35 \\
\hline $\mathrm{pH}$ & 7.29 & 7.30 & 7.42 & 7.20 & 7.17 & 7.10 & 7.19 & 7.10 & 7.20 & 7.30 & 7.22 & 7.30 \\
\hline Electrolytic conductivity $\left[\mu \mathrm{S} \cdot \mathrm{cm}^{-1}\right]$ & 438 & 749 & 766 & 748 & 373 & 503 & 497 & 502 & 862 & 997 & 990 & 999 \\
\hline
\end{tabular}

Source: Own study based on the results obtained from the Municipal Plant in Lipsk.

III, IV ,IX, XII - subsequent months

recorded in March and at piezometer No. 3, it was $8.02 \mathrm{~m}$. The average values of heights at which water was present in farm wells were: piezometer No. 1 - 20.16 m, piezometer No. 2 - 18.04 m, piezometer No. $3-10.96 \mathrm{~m}$. While analyzing the results, it can be stated that checkpoint No. 1 in a household in the village of Kurianka is a deepmine facility.

The acidity of tested water depends mainly on the type of waste deposited on the landfill and the age of landfill. The underground water around the discussed landfill had a $\mathrm{pH}$ of 7.1 to $7.42 \mathrm{pH}$ (Table 1). Over time, as a result of the decreasing amount of organic matter in these masses of deposited waste, the amount of acidic products decreased as well (Wiater 2011, Mazur 2002).

In the test water samples, the electrolytic conductivity in all piezometers ranged from $373.4 \mu \mathrm{S} \cdot \mathrm{cm}^{-1}$ to $998.8 \mu \mathrm{S} \cdot \mathrm{cm}^{-1}$ (Table 1). The dynamics of changes in the electrolytic conductivity of water is proportional to the concentration of dissolved material (Wiater 2011, Jagiełło 2003). The lowest value of electrolytic conductivity was recorded in the first piezometer and in March, while the highest value was determined in the third piezometer and in December. The increase in the conductivity is probably caused by mineral substances originated from the mineral wastes deposited in the landfill. There was a clear impact of the landfill on the value of this parameter, as evidenced by the results for waters from piezometers 1, 2 and 3. The studied landfill site deposited a certain amount of mineral waste, such as construction waste, which could contribute to the increased electrolytic conductivity of the examined waters. This illustrates the clear impact of the landfill on the value of this indicator.

The concentration of total organic carbon (TOC) is included in the total parameters used to assess the degree of water pollution (Szymański 1999, Regulation 2015). The highest OWO value was found in piezometer No. 2 and amounted to $3.03 \mathrm{mg} / \mathrm{dm}^{3}$ (March) (Figure 3). Throughout the year, the size of this parameter at this point was maintained at a high level as compared to other control points. The lowest concentration of total organic carbon was recorded in piezometer No. $1,0.47 \mathrm{mg} / \mathrm{dm}^{3}$ (September). The content of the discussed parameter in the tested waters was variable. This indicates the impact of the deposited wastes on the state of groundwater pollution near the landfill in the town of Kolonia Lipsk (Wiater 2011, Szymański K. 1999, Tałałaj 2003).

The concentration of PAH parameter in groundwater indicates the presence of an organic substance of anthropogenic origin (Szymański 1999). While analyzing the results obtained (Table 2), it can be noticed that the landfill does not affect the PAH content in the examined waters. Throughout 2015, the concentration was $<0.030 \mu \mathrm{g} / \mathrm{dm}^{3}$. Such values are provided for drinking water (Regulation 20015).

Contamination of water with elements of heavy metals (Table 3 ) is of particular importance due to the role of water in the circulation of chemical components between various elements of natural environment. It depends both on natural and anthropogenic factors (Tałałaj 203). Heavy metals are found in groundwater as a result of soil penetration of pesticides and mineral fertilizers used in agriculture on arable fields. They may also come from leachate from landfills, where waste is deposited, as well as from industrial and municipal sewage (Jagiełło 2003, Wiater 2011).

The cadmium concentration (Table 3 ) at all measuring points throughout the entire research period was $<0.03 \mathrm{mg} / \mathrm{dm}^{3}$. While comparing a given value with the limit values from the Regulation of the Minister of Environment in 2015, the test water can be defined as contaminated and not intended for consumption. The increased concentrations of cadmium in water do not clearly indicate contamination by the landfill and may result from the use of phosphate fertilizers, which are a source of cadmium in agriculture - the landfill is surrounded by arable land. This element infiltrates 

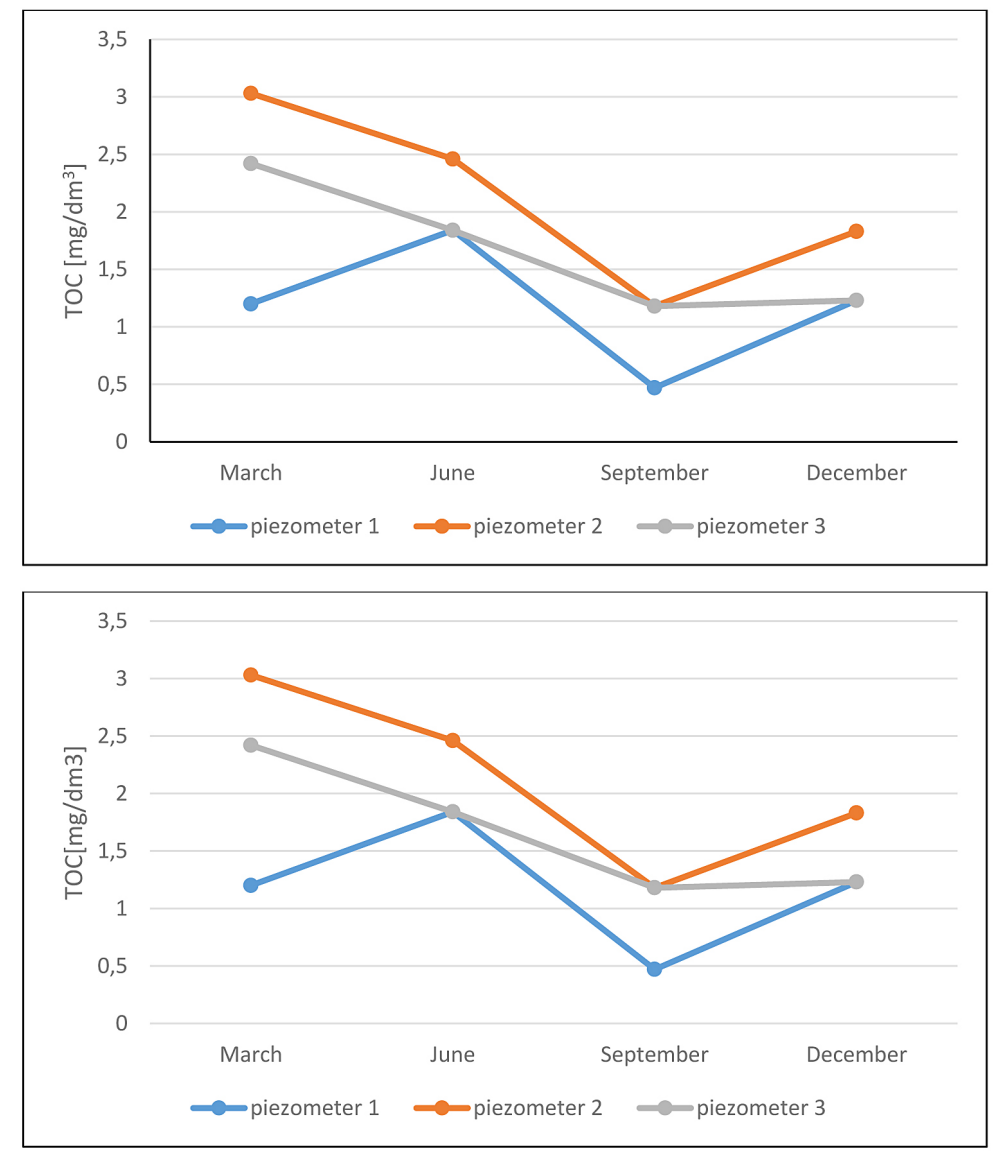

Figure 3. Changes in OWO values in piezometers around the landfill

into the soil, and then, as a result of infiltration and high activity, it penetrates into the waters (Cichy, Jaroszek, Paszek 2014). The concentration of chromium, similarly to the concentration of cadmium, at all measuring points was at the same level; its content was less than $10 \mathrm{mg} / \mathrm{dm}^{3}$ and exceeded the limit value for drinking water (Łuniewski 2003). The copper concentration in the first three quarters was equal and it amounted to $0.05 \mathrm{mg} / \mathrm{dm}^{3}$. In December, the copper concentration in piezometers 1 and 3 was $0.20 \mathrm{mg} / \mathrm{dm}^{3}$, while in piezometer $2-0.19 \mathrm{mg} / \mathrm{dm}^{3}$.

The concentration of lead (Table 3) in all piezometers throughout the year reached the same value, less than $0.10 \mathrm{mg} / \mathrm{dm}^{3}$. Therefore, the impact of the landfill on water quality is clearly noticeable.
The zinc concentration in the first quarter of 2015 was less than $0.05 \mathrm{mg} / \mathrm{dm}^{3}$, while in subsequent quarters, the zinc concentration values ranged from 0.20 to $0.64 \mathrm{mg} / \mathrm{dm}^{3}$. The only significant increase in the $\mathrm{Zn}$ concentration was recorded in September in the third piezometer $-1.39 \mathrm{mg} / \mathrm{dm}^{3}$. The concentration of mercury $(\mathrm{Hg})$ in the examined groundwater was lower than $1 \mu \mathrm{g} / \mathrm{dm}^{3}$.

\section{CONCLUSIONS}

The assessment of the groundwater quality around the landfill was made based on the results of own research and those received from the Department of Municipal Management in Lipsk. Groundwater monitoring is and will be carried

Table 2. PAHs in groundwater in studied piezometers

\begin{tabular}{|c|c|c|c|c|c|}
\hline Piezometer & Units & March & June & September & December \\
\hline 1 & $\mu \mathrm{g} / \mathrm{dm}^{3}$ & $<0.030$ & $<0.030$ & $<0.030$ & $<0.030$ \\
\hline 2 & $\mu \mathrm{g} / \mathrm{dm}^{3}$ & $<0.030$ & $<0.030$ & $<0.030$ & $<0.030$ \\
\hline 3 & $\mu \mathrm{g} / \mathrm{dm}^{3}$ & $<0.030$ & $<0.030$ & $<0.030$ & $<0.030$ \\
\hline
\end{tabular}

Source: Own study based on own results and results obtained from the Municipal Plant in Lipsk. 
Table 3. Concentration of heavy metals in tested samples

\begin{tabular}{|c|c|c|c|c|c|c|c|}
\hline \multirow{2}{*}{ Piezometer } & \multicolumn{7}{|c|}{ Metals $\left[\mathrm{mg} / \mathrm{dm}^{3}\right]$} \\
\hline & Sampling & $\mathrm{Cd}$ & $\mathrm{Cr}$ & $\mathrm{Cu}$ & $\mathrm{Pb}$ & $\mathrm{Zn}$ & $\mathrm{Hg}$ \\
\hline \multirow{4}{*}{1} & III & $<0.030$ & $<10$ & $<0.05$ & $<0.10$ & $<0.05$ & $<1$ \\
\hline & $\mathrm{VI}$ & $<0.030$ & $<10$ & $<0.05$ & $<0.10$ & 0.20 & $<1$ \\
\hline & IX & $<0.030$ & $<10$ & $<0.05$ & $<0.10$ & 0.30 & $<1$ \\
\hline & XII & $<0.030$ & $<10$ & 0.20 & $<0.10$ & 0.32 & $<1$ \\
\hline \multirow{4}{*}{2} & III & $<0.030$ & $<10$ & $<0.05$ & $<0.10$ & $<0.05$ & $<1$ \\
\hline & $\mathrm{VI}$ & $<0.030$ & $<10$ & $<0.05$ & $<0.10$ & 0.29 & $<1$ \\
\hline & IX & $<0.030$ & $<10$ & $<0.05$ & $<0.10$ & 0.64 & $<1$ \\
\hline & XII & $<0.030$ & $<1$ & $<0.19$ & $<1$ & 0.26 & $<1$ \\
\hline \multirow{4}{*}{3} & III & $<0.030$ & $<10$ & $<0.05$ & $<0.10$ & $<0.05$ & $<1$ \\
\hline & $\mathrm{VI}$ & $<0.030$ & $<10$ & $<0.05$ & $<0.10$ & 0.37 & $<1$ \\
\hline & IX & $<0.030$ & $<10$ & $<0.05$ & $<0.10$ & 1.39 & $<1$ \\
\hline & XII & $<0.030$ & $<10$ & 0.20 & $<0.10$ & 0.47 & $<1$ \\
\hline
\end{tabular}

out on the reclaimed landfill site. The research on total organic carbon and heavy metals and their concentrations in the water samples prove that groundwater is unsuitable for consumption (Regulation 2015). It has not been proven whether the cadmium contained in groundwater comes from leachate in landfills, or whether it has a fertilizer origin. Mercury, as the only heavy metal, does not exceed its content in groundwater and occurs in trace amounts.

The increased PEW values prove that the mineral substances that come from mineral waste stored in a landfill infiltrate into the waters and they can also be caused by the incoming anthropogenic pollution. The content of TOC in groundwater is the effect of the effluents entering the waters. There are sand and gravel deposits in the area of the landfill, which caused the pollution to penetrate without any obstacles.

The main cause of groundwater pollution around the discussed municipal waste landfill is the lack of the bottom sealing. The technical activities carried out as part of the reclamation project, mainly the drainage system, are likely to contribute to the improvement of groundwater quality.

On the basis of the research and the results obtained, the following conclusions were drawn:

1. Although the landfill has not been operating since 2011, it still has a negative impact on the surrounding groundwater.

2. The unambiguous influence of landfills on the increase of cadmium content in groundwater has not been proven.

3. The effluents from the landfill did not have proper drainage, which results in penetrating into the soil and subsequent contamination of groundwater.
The research was carried out as part of research work no. WZ/WBiIŚ/8/2019 at the Białystok University of Technology and financed from a subsidy provided by the Ministry of Science and Higher Education

\section{REFERENCES}

1. Bilitewski B., Hardtle G., Klaus M. 2006. Waste management guide, theory and practice, Seidel - Przywecki Publishing House, Warszawa. (in Polish)

2. Cichy B., Jaroszek H., Paszek A. 2014. Chemist 10, 68, 837. (in Polish)

3. Functional and Utility Program, Part III SIWZ. Execution of projects and reclamation of landfills in the municipalities of the Biebrza Commune Association. Elaboration: Bałakier M., Lićwinko A.

4. Jagiełł E. 2003. Contamination of groundwater by the municipal waste landfill Swojczyce. Ecological Engineering, 9, 138-144. (in Polish)

5. Korzeniewska-Rejmer E. 2003. The role of geotechnics in ensuring the safe storage of municipal waste, Magazine Technical 1-Ś/2003, Cracow University of Technology Publisher, Krakow.

6. Luniewski S. 2008. Safe storage of waste. Publishing House Economics and Environment, Bialystok. (in Polish)

7. Manczewski P., Lewicki R. 2012. Guidelines for the closure and reclamation of municipal waste landfills, Warszawa.

8. Mazur T. 2002. Agricultural chemistry, Scientific Publisher PWN, Warszawa.

9. Pleczyński J. 1999. Landfill effluent - danger and pollution of ground water, Municipal overview, 7-8. (in Polish)

10. Regulation of the Minister of Environment of 30 April 2013 on waste landfills (Dz. U. 2013 poz. $523)$. 
11. Regulation of the Minister of Environment of November 13, 2015 on the quality of water intended for human consumption (Dz.U., poz. 1989).

12. Rosik-Dulewska C. 2008. Basics of waste management, Scientific Publisher, PWN, Warszawa, (in Polish).

13. Study of Conditions and Directions of Spatial Development of the Town and Commune of Lipsk, vol. I, unified text, 2015/2016 Lipsk.

14. Szymański K. 1999. The impact of a municipal waste landfill on groundwater. 3rd International
Waste Management Forum. Technical and social aspects of waste management, Poznań, 425-444.

15. Tałałaj I. 2003. Monitoring of groundwater around communal waste landfills in the light of Polish and European Union regulations, Law and Environment, 1, 118-123, (in Polish).

16. Wiater J. 2011. The impact of municipal waste landfills on the quality of groundwater and soil properties. Ecological Engineering 26, 133-146, (in Polish). 